\title{
Induction of ovulation in seasonally anoestrous ewes by continuous infusion of low doses of Gn-RH
}

\author{
B. J. McLeod, W. Haresign and G. E. Lamming
}

A.R.C. Research Group on Hormones and Farm Animal Reproduction, University of Nottingham, Faculty of Agricultural Science, Sutton Bonington, Loughborough, Leics LE12 5RD, U.K.

\begin{abstract}
Summary. Two groups of 12 seasonally anoestrous ewes were infused with Gn-RH at the rate of 125 or $250 \mathrm{ng} / \mathrm{h}$ for $48 \mathrm{~h}$. Four control ewes were infused with the saline vehicle alone. Mean $\mathrm{LH}$ concentrations increased significantly in response to $\mathrm{Gn}-\mathrm{RH}$ infusion and were significantly higher $(P<0 \cdot 05)$ in ewes receiving $250 \mathrm{ng} \mathrm{Gn-RH/h}$. LH concentrations remained unchanged in the control ewes. Oestrus was detected in $22 / 24 \mathrm{Gn}-\mathrm{RH}$-treated ewes and occurred at a mean time of $37.0 \pm 1.2 \mathrm{~h}$ after the start of infusion. Ovulation occurred in all but one of the $24 \mathrm{Gn}$-RH-treated ewes with mean ovulation rates of $1.27 \pm 0.14(125 \mathrm{ng}-\mathrm{Gn}-\mathrm{RH} / \mathrm{h})$ and $1.75 \pm 0.22(250 \mathrm{ng} \mathrm{Gn}-\mathrm{RH} / \mathrm{h})$. These results demonstrate that a sustained elevation in mean circulating concentrations of $\mathrm{LH}$ induced by continuous administration of Gn-RH is sufficient to invoke the final phases of follicular development, and thereby ovulation, in the seasonally anoestrous ewe.
\end{abstract}

\section{Introduction}

The pattern of gonadotrophin secretion apparent during the follicular phase of the oestrous cycle in the ewe has prompted the suggestion that the final stages of follicular growth may be under the control of episodic LH secretion (Yuthasastrakosol, Palmer \& Howland, 1977; Baird, 1978). This is supported by reports that repeated injections of $\mathrm{LH}$ or $\mathrm{Gn}-\mathrm{RH}$ at frequent intervals will induce ovulation and luteal function in prepubertal lambs (Ryan \& Foster, 1980) and in seasonally anoestrous ewes (McNeilly, O’Connell \& Baird, 1982; McLeod, Haresign \& Lamming, 1982a, b). Furthermore, it has been demonstrated that, provided progesterone pretreatment is given, the $\mathrm{Gn}$ RH treatment will result in a fertile oestrus (McLeod et al., 1982b). However, it is not clear whether the LH episodes per se are necessary to stimulate follicle growth. The episodic nature of LH secretion may merely reflect a component of a self-regulating endocrine mechanism, and, if this is so, the increase in mean LH concentrations which results from an increase in episode frequency may be all that is required.

Knobil (1980) postulated that the pituitary becomes refractory to chronic administration of $\mathrm{Gn}$ RH. However, although this has been demonstrated in ewes treated with large doses $(30-300 \mu \mathrm{g})$ of Gn-RH (Crighton \& Foster, 1976, 1977), repeated low-dose (75-1000 ng) multiple injections of GnRH did not have this effect (McLeod et al., 1982a, b). The present experiment was therefore designed to investigate whether continuous infusion of low doses of $\mathrm{Gn}-\mathrm{RH}$ would result in a sustained elevation of plasma LH concentrations in seasonally anoestrous ewes and, if so, whether this would induce ovulation and normal luteal function. 


\section{Materials and Methods}

Animals and management. The 20 seasonally anoestrous Clun Forest (mean liveweight $57.8 \pm 2.0 \mathrm{~kg}$ ) and 8 Colbred $\times$ Welsh Mountain ewes (mean liveweight $46.3 \pm 1 \cdot 1 \mathrm{~kg}$ ), had all given birth to lambs the previous spring, and were used between late May and early August, 1981. During the treatment period all ewes were housed under conditions of natural daylength and temperature and fed a diet consisting of 'indoor' ewe concentrates and hay, with continuous access to fresh water. The ewes were maintained in floor-level metabolism crates throughout the infusion period, except for the short intervals when entire rams were used to detect oestrus.

Treatment and blood sampling. All ewes were fitted with bilateral indwelling jugular vein catheters, 2 days before treatment began. Ewes were infused for $48 \mathrm{~h}$ with $125 \mathrm{ng} / \mathrm{h}$ (Group 1, Ewes 1-12) or $250 \mathrm{ng} / \mathrm{h}$ (Group 2, Ewes 13-24) of Gn-RH (Lutal: Fabwerke Hoechst AG, Frankfurt, West Germany) in sterile saline $(9 \mathrm{~g} \mathrm{NaCl} / 1)$. A further 4 control ewes (Group 3, Ewes 25-28) were infused with the saline vehicle alone. The infusate was administered through one of the jugular vein catheters by means of a peristaltic pump (H-R Flow Inducer, Watson-Marlow Ltd, Falmouth, U.K.) which delivered a volume of $10 \mathrm{ml} / \mathrm{h}$. All ewes had previously undergone a 14-day pretreatment period with progesterone implants (Sil-Estrus: Abbott Laboratories, Athens, Greece) containing $375 \mathrm{mg}$ progesterone in a silicone-elastomer matrix. Three implants were inserted subcutaneously in the axilla region, and removed immediately before the start of Gn-RH infusion.

Blood samples $(2 \mathrm{ml})$ for $\mathrm{LH}$ determination were collected from the contralateral catheter and were taken from 12 ewes (Ewes 1-6 and 13-18) at 15-min intervals, from $12 \mathrm{~h}$ before the start until $12 \mathrm{~h}$ after the end of the infusion period (i.e. a total period of $72 \mathrm{~h}$ ). Samples were collected from the 4 control ewes (Ewes 25-28) at 15-min intervals from $12 \mathrm{~h}$ before the start and for the first $24 \mathrm{~h}$ of infusion, and thereafter at 2-h intervals. Blood samples for LH determination were collected from the remaining 12 ewes (Ewes 7-12 and 19-24) at 2-h intervals throughout the 72-h intensive sampling period.

Blood samples $(10 \mathrm{ml})$ for progesterone determination were collected daily by jugular venepuncture, from 3 days before until 21 days after the infusion period, and then twice weekly for a further 3 weeks.

During the frequent sampling period ewes were exposed to a colour-marked entire ram at approximately 4 -h intervals, commencing $24 \mathrm{~h}$ after the start of infusion, and allowed to mate when in oestrus. This procedure involved disconnection from the infusion apparatus for a period not exceeding $5 \mathrm{~min}$.

Laparoscopy was performed under barbiturate anaesthesia (Sagatal: May \& Baker Ltd, Dagenham, U.K.) 2 days before and 4 days after the frequent blood sampling period to assess ovarian activity.

Progesterone assay. Progesterone concentrations were measured by the radioimmunoassay method of Haresign, Foster, Haynes, Crighton \& Lamming (1975). The assay showed negligible cross-reaction with other major steroids. The limit of sensitivity within this study was $0.3 \mathrm{ng} / \mathrm{ml}$ plasma, the inter- and intra-assay coefficients of variation were both $<10 \%$, and the mean extraction efficiency was $72 \cdot 6 \%$.

LH assay. Plasma LH concentrations were determined by the specific double-antibody radioimmunoassay of Foster \& Crighton (1974) as modified by McLeod et al. (1982a). The limit of sensitivity of the assay was $0.3 \mathrm{ng} \mathrm{NIH-LH-S18} \mathrm{equiv./ml} \mathrm{plasma} \mathrm{and} \mathrm{the} \mathrm{inter-} \mathrm{and} \mathrm{intra-assay}$ coefficients of variation were $9.7 \%$ and $12.0 \%$ respectively. An LH episode was defined by the criteria of McLeod et al. (1982a); i.e. (i) an increase of at least $50 \%$ above the preceding baseline, (ii) at least two sample points between the peak value and the succeeding trough or baseline, (iii) a rate of decline in concentrations after the peak value no greater than the known half-life of the hormone.

Statistical analysis was by $\chi^{2}$ tests, Student's $t$-test or analysis of variance as appropriate. 


\section{Results}

\section{Oestrus and ovulation}

When examined by laparoscopy 2 days before the infusion period all ewes had regressed reproductive tracts typical of the seasonally anoestrous ewe, with little or no evidence of follicular development. At the second laparoscopy 4 days after the end of the Gn-RH infusion, all but one of the ewes treated with $\mathrm{Gn}-\mathrm{RH}$ had ovulated and the resultant corpora lutea were macroscopically normal. In Ewe 8 (Group 1) the catheter had become dislodged from the jugular vein and therefore the infusion was subcutaneous, rather than intravenous. None of the 4 saline-treated ewes ovulated, or showed any evidence of recent follicular development. Ovulation rates for the different groups are given in Table 1.

Table 1. Oestrus, ovulation rate and preovulatory $\mathrm{LH}$ release in seasonally anoestrous ewes given a continuous intravenous infusion of Gn-RH for $48 \mathrm{~h}$

\begin{tabular}{cccccc}
\hline Group & $\begin{array}{c}\text { Gn-RH } \\
\text { dose (ng/h) }\end{array}$ & $\begin{array}{c}\text { No. of } \\
\text { ewes ovulating }\end{array}$ & $\begin{array}{c}\text { Mean } \pm \text { s.e.m. } \\
\text { ovulation rate }\end{array}$ & $\begin{array}{c}\text { No. of ewes in } \\
\text { oestrus }\end{array}$ & $\begin{array}{c}\text { Mean } \pm \text { s.e.m. } \\
\text { interval to LH peak (h) }\end{array}$ \\
\hline 1 & 125 & $11 / 12^{*}$ & $1 \cdot 27 \pm 0 \cdot 14$ & $10 / 12^{*}$ & $36 \cdot 1 \pm 2 \cdot 9$ \\
2 & 250 & $12 / 12$ & $1 \cdot 75 \pm 0 \cdot 22$ & $12 / 12$ & $34 \cdot 7 \pm 2 \cdot 0$ \\
3 & 0 (saline) & $0 / 4$ & \pm & - & - \\
\hline
\end{tabular}

* One ewe lost its progesterone implants before Gn-RH infusion and another ewe was infused subcutaneously (see text).

All except one of the ewes that ovulated displayed oestrus, at a mean ( \pm s.e.m.) time interval of $37 \cdot 0 \pm 1 \cdot 2 \mathrm{~h}(n=22)$ after the start of the Gn-RH infusion, with no significant difference between treatment groups. Ewe 4 (Group 1) was found to have lost its progesterone implants at the start of the infusion period and therefore was not progesterone-primed. None of the saline-treated control ewes showed oestrus (Table 1).

\section{LH concentrations}

Over the 12-h pretreatment period, LH concentrations were basal (Table 2) and included a mean of $1.3 \pm 0.3 \mathrm{LH}$ episodes with no significant differences between treatment groups. At the start of Gn-RH infusion, plasma LH values rose immediately and remained elevated until the onset of a preovulatory LH peak. The mean LH profiles for ewes sampled at 15 -min intervals in each GnRH treatment group are shown in Text-fig. 1. There was considerable variation in plasma LH concentrations (Text-fig. 2), in spite of a continuous rate of Gn-RH infusion. During the period between the start of Gn-RH infusion and the onset of the preovulatory LH surge, LH episodes occurred at a rate of $2.4 \pm 0.3$ per $12 \mathrm{~h}$, which was significantly $(P<0.05)$ greater than that observed during the pretreatment period.

Group mean LH concentrations (based on 2-h samples from all ewes) over various periods in relation to the start of Gn-RH infusion for the different treatment groups are given in Table 2 . In both groups the elevation in $\mathrm{LH}$ concentrations as a result of $\mathrm{Gn}-\mathrm{RH}$ administration was significant $(P<0.001)$, whereas plasma LH concentrations in saline-treated ewes (Group 3) remained unchanged throughout. Moreover, mean LH levels during the period from the start of Gn-RH infusion until the onset of the preovulatory LH peak were significantly greater in ewes receiving $250 \mathrm{ng} \mathrm{Gn-RH/h}$. This difference was greatest over the first $12 \mathrm{~h}$ of infusion.

A preovulatory LH peak occurred in all but 3 of the Gn-RH-treated ewes during the frequent blood sampling period. Of these 3 ewes, Ewe 4 had lost its progesterone implants before Gn-RH treatment and had sustained high LH concentrations at the start of the infusion and Ewe 8 was 


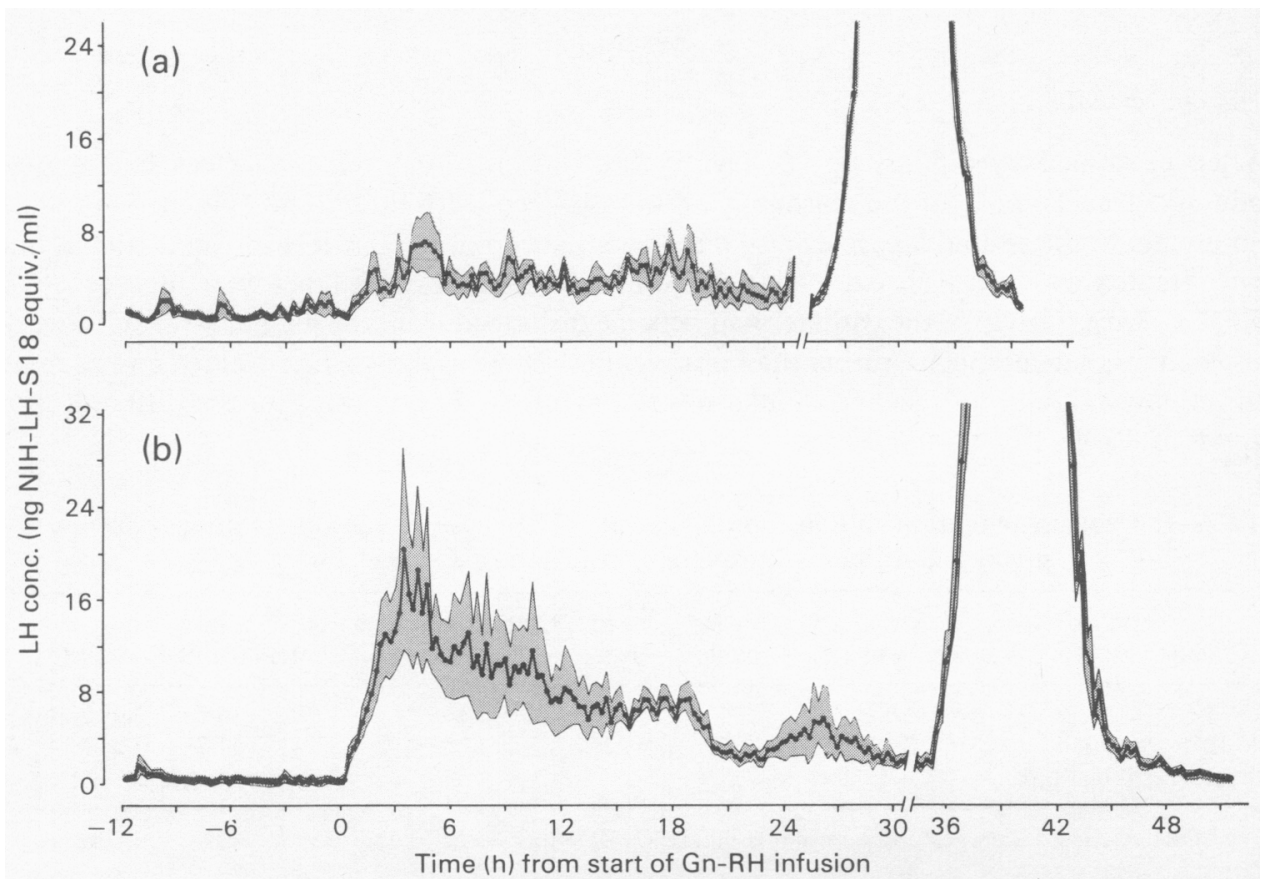

Text-fig. 1. Mean ( \pm s.e.m.) plasma LH concentrations in seasonally anoestrous ewes before and in response to continuous i.v. infusion for $48 \mathrm{~h}$ of (a) $125 \mathrm{ng} \mathrm{Gn}-\mathrm{RH} / \mathrm{h}$ or (b) $250 \mathrm{ng} \mathrm{Gn}$ $\mathrm{RH} / \mathrm{h}$. The mean is shown as the solid line with the s.e.m. bounded by the fine lines.

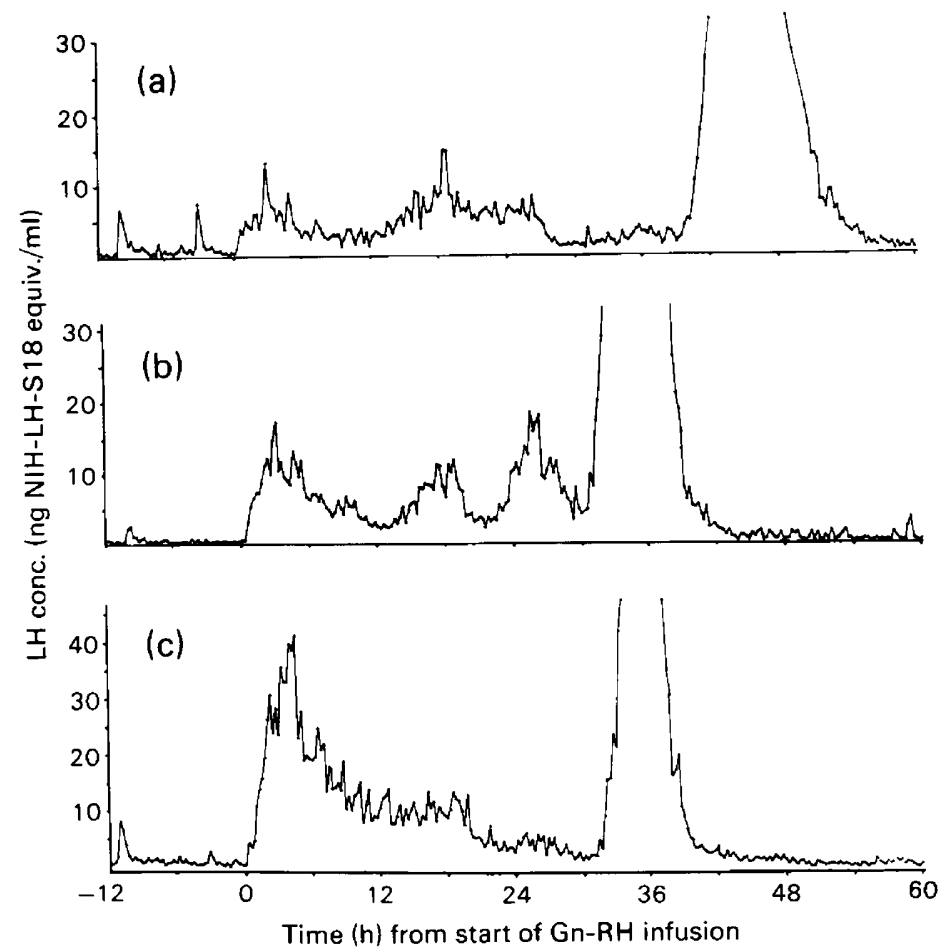

Text-fig. 2. Plasma LH concentrations in 3 seasonally anoestrous ewes before and in response to continuous i.v. infusion of Gn-RH for $48 \mathrm{~h}$ : (a) Ewe 1, $125 \mathrm{ng} \mathrm{Gn}-\mathrm{RH} / \mathrm{h}$; (b) Ewe 13, $250 \mathrm{ng}$ $\mathrm{Gn}-\mathrm{RH} / \mathrm{h}$; (c) Ewe 15, $250 \mathrm{ng} \mathrm{Gn}-\mathrm{RH} / \mathrm{h}$. 
Table 2. Mean \pm s.e.m. plasma LH concentrations (samples collected at 2 -h intervals) in seasonally anoestrous ewes infused with $125 \mathrm{ng} \mathrm{Gn}-\mathrm{RH} / \mathrm{h}, 250 \mathrm{ng} \mathrm{Gn}-\mathrm{RH} / \mathrm{h}$ or saline for $48 \mathrm{~h}$

LH conc. (ng NIH-LH-S18 equiv./ml)

\begin{tabular}{|c|c|c|c|c|c|c|}
\hline \multirow[b]{3}{*}{ Group } & \multirow[b]{3}{*}{$\begin{array}{l}\text { Gn-RH dose } \\
(\mathrm{ng} / \mathrm{h})\end{array}$} & \multirow[b]{3}{*}{$\begin{array}{l}\text { No. of } \\
\text { ewes }\end{array}$} & \multirow{2}{*}{\multicolumn{4}{|c|}{ Period from start of infusion }} \\
\hline & & & & & & \\
\hline & & & -12 to $0 \mathrm{~h}$ & $0-12 \mathrm{~h}$ & $12-24 \mathrm{~h}$ & $\begin{array}{l}\text { Start of infusion to } \\
\text { preovulatory LH peak }\end{array}$ \\
\hline 1 & 125 & $10^{*}$ & $1.07 \pm 0.09^{a}$ & $6.76 \pm 1.27^{\mathrm{b}}$ & $5.05 \pm 0.90^{\mathrm{b}}$ & $5.60 \pm 0.81^{b}$ \\
\hline 2 & 250 & $11 \dagger$ & $1.08 \pm 0.58^{\mathrm{a}}$ & $14.49 \pm 2.22^{\mathrm{bc}}$ & $8.92 \pm 2.07^{\mathrm{b}}$ & $11.37 \pm 2.03^{\mathrm{bd}}$ \\
\hline 3 & 0 (saline) & 4 & $0.88 \pm 0.24^{\mathrm{a}}$ & $1.21 \pm 0.22^{\mathrm{a}}$ & $1 \cdot 11 \pm 0 \cdot 19^{a}$ & $1.21 \pm 0.15^{\mathrm{a}}$ \\
\hline
\end{tabular}

* Excludes Ewe 4 which lost its progesterone implants, and Ewe 8 which was infused subcutaneously.

$\dagger$ Excludes Ewe 18 in which the preovulatory LH peak was not monitored.

Within columns, means with different superscripts are significantly different: $\mathrm{a}-\mathrm{b}, P<0.001 ; \mathrm{b}-\mathrm{c} P<0.01 ; \mathrm{b}-\mathrm{d}, P$ $<0.05$.

infused subcutaneously. The mean ( \pm s.e.m.) interval between the start of $\mathrm{Gn}-\mathrm{RH}$ infusion and the onset of the preovulatory $\mathrm{LH}$ peak (125 ng Gn-RH/h, 36.1 $\pm 2.9 \mathrm{~h}$; range $24 \cdot 25-45 \cdot 25 \mathrm{~h}: 250 \mathrm{ng}$ $\mathrm{Gn}-\mathrm{RH} / \mathrm{h}, 34 \cdot 7 \pm 2 \cdot 0 \mathrm{~h}$; range $28 \cdot 00-50 \cdot 00 \mathrm{~h}$ ) was not significantly influenced by dose of Gn-RH.

\section{Progesterone concentrations}

All 23 of the Gn-RH-treated ewes that ovulated displayed a normal luteal pattern of progesterone secretion, which was defined as an elevation in plasma progesterone concentrations for at least 9 days, starting within 5 days of the preovulatory LH surge and reaching a maximum concentration of $>1.5 \mathrm{ng} / \mathrm{ml}$. In all $\mathrm{Gn}-\mathrm{RH}$-treated ewes plasma progesterone levels rose approximately 3-4 days after the end of infusion and, in 6 ewes in Group 1 and 6 ewes in Group 2, fell 10-12 days later, a pattern typical of the normally cyclic ewe. In the remaining 11 ewes, plasma progesterone concentrations remained elevated throughout the sampling period, indicative of pregnancy.

\section{Discussion}

The pattern of $\mathrm{LH}$ secretion in response to continuous infusion of $\mathrm{Gn}-\mathrm{RH}$ for $48 \mathrm{~h}$ in anoestrous ewes has demonstrated that this treatment results in a sustained elevation of mean LH concentrations. There was considerable individual variation between animals in the pattern of LH release (see Text-fig. 2), but no diurnal or circadian rhythms were apparent. In spite of the markedly fluctuating $\mathrm{LH}$ levels throughout the period of $\mathrm{Gn}-\mathrm{RH}$ infusion, concentrations were always significantly greater than pretreatment values. Although there was a small, but significant, increase in $\mathrm{LH}$ episode frequency during the period from the start of $\mathrm{Gn}-\mathrm{RH}$ infusion up to the time of the preovulatory LH surge, the data illustrated in Text-fig. 2 are suggestive of a much higher episode frequency than that calculated using the definition of McLeod et al. (1982a). Such rigid criteria for defining LH episodes are appropriate when episode frequency is low and baseline concentrations relatively stable (pretreatment period), but when episode frequency is high and baseline concentrations constantly changing ( $\mathrm{Gn}-\mathrm{RH}$ infusion period) it becomes very difficult to satisfy them. In such situations a higher sampling frequency (every $4 \mathrm{~min}$ ) would identify a greater proportion of LH episodes (F. J. Karsch, unpublished), although a change in the criteria for identification might be more appropriate. A major difficulty is to find a definition which can be statistically evaluated, yet is sufficiently sensitive to identify all LH episodes. 
The sustained elevation in LH concentrations with continuous infusion of Gn-RH, at least with the short treatment duration used in the present trial, would not appear to be entirely consistent with the phenomenon of pituitary 'down regulation' which would be predicted from rhesus monkey data (Knobil, 1980). This may be attributable to the very large differences in dose levels used when expressed on a $\mathrm{ng} / \mathrm{kg}$ bodyweight $/ \mathrm{h}$ basis, the use of a different animal model (ovariectomized, hypothalamic-lesioned monkeys compared to entire, seasonally anoestrous ewes) or the different sampling frequencies and time periods of the respective experiments.

Although the mean LH profile of ewes infused with the higher dose of Gn-RH (Text-fig. 1b) could be interpreted as representing 'down regulation', this overall mean pattern is largely attributable to the profiles of only $2 / 6$ ewes (see Text-fig. $2 \mathrm{c}$ ). In the remaining 4 ewes treated with $250 \mathrm{ng} \mathrm{Gn}-\mathrm{RH} / \mathrm{h}$, and in all 6 ewes treated with $125 \mathrm{ng} \mathrm{Gn-RH/h}$ and bled at $15-\mathrm{min}$ intervals, plasma LH concentrations did not decline continuously from the start of infusion up to the time of the preovulatory LH peak. Rather, they showed periods when levels were elevated, interspersed with periods of lower concentrations (see Text-fig. 2a, b). Furthermore, we would suggest that the fall in LH concentrations immediately before the $\mathrm{LH}$ surge reflects high oestradiol levels at this time and is therefore indicative of steroid modulation of the hypothalamic-pituitary axis, not pituitary 'down regulation'. In addition, the pattern of LH secretion illustrated in Text-fig. 2(b) and evident in several of the ewes at both dose levels may also reflect modulation of pituitary response induced by changing steroid concentrations from developing follicles. Further work is required to clarify these possibilities.

It has been suggested that the increase in LH episode frequency which occurs during the follicular phase of the cycle in the ewe is directly responsible for the final stages of follicular growth (Yuthasastrakosol et al., 1977; Baird, 1978; McLeod et al., 1982a, b; McNeilly et al., 1982). The fact that ovulation occurred in all but 1 of 24 ewes infused with Gn-RH in the present trial may indicate that it is the increase in mean concentrations rather than the episodic pattern per se which is responsible for promoting follicular maturation and oestrogen secretion. However, since LH concentrations still showed evidence of an episodic mode of secretion even in the face of a continuous rate of $\mathrm{Gn}-\mathrm{RH}$ infusion the relative importance of these features of $\mathrm{LH}$ secretion could not be determined by these data.

The difference in ovulation rate between animals infused with 125 compared with $250 \mathrm{ng}$ Gn$\mathrm{RH} / \mathrm{h}$ was not significant, probably because of the small numbers of animals used to monitor a discontinuous variate. However, this difference was associated with a significant difference in mean LH concentrations. A similar correlation between $\mathrm{LH}$ concentrations and ovulation rate was evident when anoestrous ewes were treated with repeated injections of low doses of Gn-RH, although with the small numbers of animals involved the differences in ovulation rate were again not significant (McLeod et al., 1982b). If, as is suggested by these data, an increase in mean LH concentrations is responsible for the final stages of follicular growth, then a positive relationship may exist between mean LH concentrations during the follicular phase of the cycle and subsequent ovulation rate, but further work is required to investigate this possibility.

These data do not preclude the possible involvement of FSH in the responses noted. However, although FSH was not measured in this trial, there were no apparent changes in FSH concentrations in anoestrous ewes treated with multiple injections of Gn-RH for $48 \mathrm{~h}$ (B. J. McLeod \& W. Haresign, unpublished data). Furthermore, McNeilly et al. (1982) have shown that similar results can be achieved by injection of purified $\mathrm{LH}$ alone, precluding a change in FSH secretion as an important component of the responses noted. Similar work in the ram has shown that, although there is an immediate $\mathrm{LH}$ response to low-dose Gn-RH injections, plasma FSH concentrations did not increase until after 4 days of treatment (Lincoln, 1979).

These data support earlier reports that seasonal anoestrus in the ewe is characterized by an inadequate pattern of LH secretion (McLeod et al., 1982a, b; McNeilly et al., 1982), and indicate that it is possible to restore ovulation and normal luteal function in the progesterone-primed anoestrous ewe by continuous infusion of $\mathrm{Gn}-\mathrm{RH}$. 
We thank the A.R.C. and Hoechst Pharmaceuticals for financial support; Hoechst Pharmaceuticals for supplies of synthetic Gn-RH; the National Institutes of Health for standard $\mathrm{LH}$; and Abbott Laboratories for the progesterone implants.

\section{References}

Baird, D.T. (1978) Pulsatile secretion of LH and ovarian estradiol during the follicular phase of the sheep estrous cycle. Biol. Reprod. 18, 359-364.

Crighton, D.B. \& Foster, J.P. (1976) Effects of duplicate injections of synthetic luteinizing hormone releasing hormone at various intervals on luteinizing hormone release in the anoestrous ewe. $J$. Endocr. 69, 36P$37 P$.

Crighton, D.B. \& Foster, J.P. (1977) Luteinizing hormone release after two injections of synthetic luteinizing hormone releasing hormone in the ewe. $J$. Endocr. 72, 59-67.

Foster, J.P. \& Crighton, D.B. (1974) Luteinizing hormone (LH) release after single injections of a synthetic LH-releasing hormone (LH-RH) in the ewe at three different reproductive stages and comparison with natural LH release at oestrus. Theriogenology 2 , $87-100$.

Haresign, W., Foster, J.P., Haynes, N.B., Crighton, D.B. \& Lamming, G.E. (1975) Progesterone levels following treatment of seasonally anoestrous ewes with synthetic LH-releasing hormone. J. Reprod. Fert. 43, 269-279.

Knobil, E. (1980) The neuroendocrine control of the menstrual cycle. Recent Prog. Horm. Res. 36, 53-88.
Lincoln, G.A. (1979) Use of a pulsed infusion of luteinizing hormone-releasing hormone to mimic seasonally induced endocrine changes in the ram. $J$. Endocr. 83, 251-260.

McLeod, B.J., Haresign, W. \& Lamming, G.E. (1982a) The induction of ovulation and luteal function in seasonally anoestrous ewes treated with small-dose multiple injections of LH-RH. J. Reprod. Fert. 65, 215-221.

McLeod, B.J., Haresign, W. \& Lamming, G.E. (1982b) Response of seasonally anoestrous ewes to small-dose multiple injections of Gn-RH with and without progesterone pretreatment. J. Reprod. Fert. 65, 223230.

McNeilly, A.S., O'Connell, M. \& Baird, D.T. (1982) Induction of ovulation and normal luteal function by pulsed injections of luteinizing hormone in anestrous ewes. Endocrinology 110, 1292-1299.

Ryan, K.D. \& Foster, D.L. (1980) Neuroendocrine mechanisms involved in onset of puberty in the female: concepts derived from the lamb. Fedn Proc. Fedn Am. Socs exp. Biol. 39, 2372-2377.

Yuthasastrakosol, P., Palmer, W.M. \& Howland, B.E. (1977) Release of LH in anoestrous and cyclic ewes. $J$. Reprod. Fert. 50, 319-321.

Received 16 August 1982 